\title{
BIBLIOGRAPHIE / BIBLIOGRAPHY
}

Die nachfolgende Literaturauswahl ist erstellt in Zusammenarbeit mit dem Informationszentrum des Leibniz-Instituts für Globale und Regionale Studien - GIGA - (bis 2005: Deutsches Übersee-Institut - DÜI) Hamburg.*

The following selected bibliography has been compiled in cooperation with the information centre of the German Institute of Global and Area Studies - GIGA - (former German Overseas Institute - DÜI) Hamburg.**

\section{RECHT UND ENTWICKLUNG ALLGEMEIN / LAW AND DEVELOPMENT IN GENERAL}

Beaulieu, Emily / Hyde, Susan D., In the shadow of democracy promotion: strategic manipulation, international observers, and election boycotts, in: Comparative Political Studies (Thousand Oaks/Cal.). 42 (March 2009) 3, S. 392-415.

Bertelsmann Transformation Index 2008: Politische Gestaltung im internationalen Vergleich / [Verantw.: Olaf Hillenbrand]. Bertelsmann Stiftung.- Gütersloh: Verlag Bertelsmann Stiftung, 2008, 243 S. + 1 CD-ROM.- ISBN 978-3-89204-967-8.

Hermet, Guy, Exporter la démocratie?.- Paris: Presses de Sciences Po, 2008, 138 S.- ISBN 978-27246-1078-9.

Kulkarni, Parashar, Impact of the GATS on basic social services redux, in: Journal of World Trade (London). 43 (April 2009) 2, S. 245-283.

Nuscheler, Franz, Die umstrittene Wirksamkeit der Entwicklungszusammenarbeit.- Duisburg: Institut für Entwicklung und Frieden, 2008, 42 S.

Reinventing foreign aid / ed. by William Easterly. Foreword by Nancy Birdsall.- Cambridge/Mass u.a.: MIT Pr., 2008, X, 567 S.- ISBN 978-0-262-55066-6.

\section{AFRIKA / AFRICA}

Carlowitz, Leopold von, Local ownership and the rule of law in Liberia, in: Recht in Afrika (Köln). 11 (2008) 1, S. 71-81.

Cranenburgh, Oda van, 'Big men' rule: presidential power, regime type and democracy in 30 African countries, in: Democratization (Abingdon). 15 (December 2008) 5, S. 952-973.

* Diese Bibliographie dient ausschließlich der Information. Die angegebenen Titel können von VRÜ und GIGA nicht geliefert werden.

** This Bibliography serves information purposes only. Neither VRÜ nor GIGA can supply any of the titles listed. 
Date-Bah, S. K., Judging in Ghana: some reflections, in: Recht in Afrika (Köln). 11 (2008) 1, S. 6170.

Dynamique participative pour l'émergence d'un Etat de droit en Afrique: exemple de la Guinée / IFES, Fondation Internationale pour les Systèmes Electoraux.- Paris: L'Harmattan, 2008, 154 S.- ISBN 978-2-296-05342-7.

Eberlei, Walter, Wachsender Einfluss zivilgesellschaftlicher Akteure in afrikanischen Entwicklungsprozessen, in: Afrika Spectrum (Hamburg). 43 (2008) 3, S. 309-331.

Feris, Loretta, Constitutional environmental rights: an under-utilised resource, in: South African Journal on Human Rights (Lansdowne). 24 (2008) 1, S. 29-49.

Gumede, William Mervin, Modernising the African National Congress: the legacy of President Thabo Mbeki, aus: State of the nation: South Africa 2008 / ed. by Peter Kagwanja u.a. Human Sciences Research Council.- Cape Town: HSRC Press, 2009.- (State of the Nation: South Africa; 5), S. 3557.- ISBN 978-07969-2199-4.

Howard-Hassmann, Rhoda E., Reparations to Africa.- Philadelphia/Pa.: University of Pennsylvania Press, 2008, 257 S.- ISBN 978-0-8122-4101-3.

Kabanda, Médard Mpiana, Nichtregierungsorganisationen als Herz der Zivilgesellschaft und Säule der Demokratie in Zentralafrika?: Staaten und freiwillige Organisationen am Beispiel der Demokratischen Republik Kongo.- Osnabrück: Koentopp, 2008, X, 314 S.- ISBN 978-3-938342-13-8.

Land rights are human rights: win-win strategies for sustainable nature conservation contributions from South Africa / eds.: Thora Amend u.a. Publ. by Deutsche Gesellschaft für Technische Zusammenarbeit.- Eschborn: GTZ, 2008, 60 S.

Liberia: Land der Freien - Last der Freiheit / Hrsg.: Evangelisches Missionswerk in Deutschland. Realisierung: Sabine Förster u.a.. Redaktion: Freddy Dutz.- Hamburg: EMW, 2009, 296 S.

Logan, Carolyn, Selected chiefs, elected councillors and hybrid democrats: popular perspectives on the co-existence of democracy and traditional authority, in: The Journal of Modern African Studies (Cambridge). 47 (March 2009) 1, S. 101-128.

Madlener, Kurt, Conflict resolution in sub-Saharan Africa: an overview, in: Recht in Afrika (Köln). 11 (2008) 1, S. 19-32.

Makara, Sabiti / Rakner, Lise / Svasand, Lars, Turnaround: the National Resistance Movement and the reintroduction of a multiparty system in Uganda, in: International Political Science Review (London). 30 (March 2009) 2, S. 185-204.

Mbazira, Christopher, From ambivalence to certainty: norms and principles for the structural interdict in socio-economic rights litigation in South Africa, in: South African Journal on Human Rights (Lansdowne). 24 (2008) 1, S. 1-28.

Monitoring des jurisdictions gacaca: phase de jugement / Avocats sans Frontières.- Kigali, 2005-

N'Diaye, Boubacar, To 'midwife' - and abort - a democracy: Mauritania's transition from military rule, 2005-2008, in: The Journal of Modern African Studies (Cambridge). 47 (March 2009) 1, S. 129-152.

Nga Beyeme, Crescence, Le droit international de la femme et son application dans le contexte africain: le cas des mutilations génitales féminines.- Frankfurt/Main u.a.: Peter Lang, 2009, 322 S.ISBN 978-3-631-58528-3. 
Ondo, Télesphore, Le droit parlementaire gabonais.- Paris: L'Harmattan, 2008, 407 S.- ISBN 978-2296-05552-0.

Peter, Chris Maina, Access to justice: creating a role for paralegals in the administration of justice in Africa, in: Recht in Afrika (Köln). 11 (2008) 1, S. 101-129.

La recherche scientifique et le développement en Afrique: idées nomades / Stéphane Bell (éd.). Préface de Mariama Hima Yankori.- Paris: Karthala, 2008, 274 S.- ISBN 978-2-8111-0005-6.

Rotberg, Robert I., Governance and leadership in Africa: measures, methods and results, in: Journal of International Affairs (New York/N.Y.). 62 (Spring-Summer 2009) 2, S. 113-126.

Simutanyi, Neo, One-party dominance and democracy in Zambia: studies on political parties and democracy.- Maputo: Friedrich-Ebert-Stiftung, 2008, 28 S.

Suberu, Rotimi, Federalism in Africa: the Nigerian experience in comparative perspective, in: Ethnopolitics (Basingstoke). 8 (March 2009) 1, Special issue: federalism, regional autonomy and conflict, S. 67-86.

Wanitzek, Ulrike, Women's and children's rights in Africa: a case study of international human rights and family law in Tanzanian courts, in: Recht in Afrika (Köln). 11 (2008) 1, S. 33-60.

Whitaker, Beth Elise / Giersch, Jason, Voting on a constitution: implications for democracy in Kenya, in: Journal of Contemporary African Studies (Basingstoke). 27 (January 2009) 1, S. 1-20.

\section{ASIEN / ASIA}

Abdul-Rahman, Noor Aisha, Muslim personal law within the Singapore legal system: history, prospects and challenges, in: Journal of Muslim Minority Affairs (London). 29 (March 2009) 1, S. 109-126.

Carnegie, Paul J., Democratization and decentralization in post-Sueharto Indonesia: understanding transition dynamics, in: Pacific Affairs (Vancouver). 81 (Winter 2008-2009) 4, S. 515-526.

China: defining the boundary between the market and the state / Organisation for Economic Cooperation and Development.- Paris: Organisation for Economic Co-operation and Development, 2009, 320 S.- ISBN 978-92-64-05939-9.

Chou, Chih Chieh, Bridging the global and the local: China's effort at linking human rights discourse and neo-Confucianism, in: China Report (New Delhi). 44 (May 2008) 2, S. 139-152.

Deepening democracy in Indonesia?: Direct elections for local leaders (pilkada) / ed. by Maribeth Erb u.a. Institute of Southeast Asian Studies.- Singapore: ISEAS, 2009, XXV, 392 S.- ISBN 978-981230-840-5.

Desierto, Diane A., Universalist constitutionalism in the Philippines: restricting executive particularism in the form of executive privilege, in: Verfassung und Recht in Übersee (Baden-Baden). 42 (2009) 1, S. 80-105.

Focus: intellectual property / Ryan Ong u.a. , in: The China Business Review (Washington/D.C.). 36 (March-April 2009) 2, S. 17-35.

Frank-Fahle, Constantin, Die besondere Rolle der reservierten Maori-Sitze im System des personalisierten Verhältniswahlrechts Neuseelands, Verfassung und Recht in Übersee (Baden-Baden). 42 (2009) 1, S. 34-54. 
Gilley, Bruce / Holbig, Heike, The debate on party legitimacy in China: a mixed quantitative/qualitative analysis, in: The Journal of Contemporary China (Abingdon). 18 (March 2009) 59, S. 339358.

Gutschker, Thomas, Die Hölle vor Gericht: 30 Jahre nach dem Sturz der Roten Khmer hat in Kambodscha die Aufarbeitung ihrer Verbrechen begonnen, in: Internationale Politik / Deutsche Gesellschaft für Auswärtige Politik (Bielefeld). 64 (April 2009) 4, S. 68-75.

Hewitt, Vernon, Political mobilisation and democracy in India: states of emergency.- Abingdon u.a.: Routledge, 2008, IX, 230 S.- ISBN 0-415-42375-9.

Hicken, Allen, Building party systems in developing democracies.- Cambridge: Cambridge Univ. Press, 2009, XI, 207 S.- ISBN 978-0-521-88534-8.

Krämer, Karl-Heinz, Das Ende der nepalischen Monarchie: demokratischer Aufbruch oder andauernde Krise?, in: Internationales Asienforum (Freiburg/Breisgau). 39 (November 2008) 3-4, S. 221-248.

Kuehn, David, Democratization and civilian control of the military in Taiwan, in: Democratization (Abingdon). 15 (December 2008) 5, S. 870-890.

Landry, Pierre F., Does the Communist Party help strengthen China's legal reforms?, in: China Review (Hong Kong). 9 (Spring 2009) 1, Special issue: markets, courts and Leninism, S. 45-71.

Manea, Maria-Gabriela, How and why interaction matters: ASEAN's regional identity and human rights, in: Cooperation and Conflict (London). 44 (March 2009) 1, S. 27-49.

Muhammad, Ramizah Wan, Shari'ah Court judges and judicial creativity (Ijtihad) in Malaysia and Thailand: a comparative study, in: Journal of Muslim Minority Affairs (London). 29 (March 2009) 1, S. 127-140.

Ooi, Su-mei, The transnational protection regime and Taiwan's democratization, in: Journal of East Asian Studies (Boulder/Colo.). 9 (January-April 2009) 1, S. 57-85.

Schubert, Gunter / Heberer, Thomas, Der ländliche Raum.- Wiesbaden: VS Verl. für Sozialwissenschaften, 2009, 270 S.- ISBN 978-3-531-16069-6.

Shen, Kui, "Democratization" of judicial interpretation and the Supreme Court's political function, in: Social Sciences in China (Beijing). 29 (November 2008) 4, S. 33-47.

Tang, Wenfang, Rule of law and dispute resolution in China: evidence from survey data, in: China Review (Hong Kong). 9 (Spring 2009) 1, Special issue: markets, courts and Leninism, S. 73-96.

Thapa, Ganga Bahadur / Sharma, Jan, From insurgency to democracy: the challenges of peace and democracy-building in Nepal, in: International Political Science Review (London). 30 (March 2009) 2, S. 205-219.

Thayer, Carlyle A., Vietnam and the challenge of political civil society, in: Contemporary Southeast Asia (Singapore). 31 (April 2009) 1, S. 1-27.

Xanthaki, Alexandra / O'Sullivan, Dominic, Indigenous participation in elective bodies: the Maori in New Zealand, in: International Journal on Minority and Group Rights (Leiden). 16 (2009) 2, S. 181-2007.

Zheng, Yongnian / Yang, Lijun / Guo, Xiajuan, Women's participation in village autonomy in China: evidence from Zhejiang province, in: The China Quarterly (London). (March 2009) 197, S. 145164. 


\section{NAHER UND MITTLERER OSTEN / NEAR AND MIDDLE EAST}

Aksikas, Jaafar, Arab modernities: Islamism, nationalism, and liberalism in the post-colonial Arab world.- New York: Lang, 2009, 177 S.- ISBN 978-1-4331-0534-0.

Aliyev, Rakhat, The Godfather-in-law: eine Dokumentation.- Wien: Ibera, 2009, 532 S.- ISBN 978-385052-277-9.

Arato, Andrew, Constitution making under occupation: the politics of imposed revolution in Iraq.New York/N.Y.: Columbia Univ. Press, 2009, XIII,360 S.- ISBN 978-0-231-14302-8.

Bentlage, Björn, Protest im Anzug: der ägyptische Richterclub und der Konflikt mit dem Justizministerium, 2000-2007.- Hamburg: EB-Verl., 2008, 73 S.- ISBN 978-3-936912-93-7.

Broschk, Florian, Gottes Gesetz zwischen Elfenbeinturm und Außenpolitik: "Schiitisches Völkerrecht" in der Islamischen Republik Iran.- Hamburg: EB-Verl., 2008, 69 S.- ISBN 978-3-93691266-1.

Central Asia: an overview: hearing before the Subcommittee on Asia, the Pacific, and the Global Environment of the Committee on Foreign Affairs, U.S. House of Representatives, 110th Congress, 2nd Session, April 8, 2008.- Washington/D.C.: U.S. Government Printing Office, 2008, III, $40 \mathrm{~S}$.

Duncker, Anne, Menschenrechtsorganisationen in der Türkei.- Wiesbaden: VS Verl. für Sozialwissenschaften, 2009, 264 S.- ISBN 978-3-531-16245-4.

Ferrié, Jean-Noël, L'Egypte entre démocratie et islamisme: le système Moubarak à l'heure de la succession.- Paris: Ed. Autrement, 2008, 124 S.- ISBN 978-2-7467-1190-7.

Judges and political reform in Egypt / ed. by Nathalie Bernard-Maugiron.- Cairo u.a.: American Univ. in Cairo Press, 2008, XIII, 312 S.- ISBN 978-977-416201-5.

Kachkeev, Maksat, Die Verfassungsreform in Turkmenistan, in: Osteuropa-Recht (Berlin). 55 (März 2009) 1, S. 66-75.

Lehner, Oskar, Respecting human rights in Central Asia: will this stabilize or destabilize the region?, in: Security and Human Rights (Leiden). 20 (2009) 1, S. 48-55.

Moon, Bruce E., Long time coming: prospects for democracy in Iraq, in: International Security (Cambridge/Mass.). 33 (Spring 2009) 4, S. 115-148.

Muravchik, Joshua, The next founders: voices of democracy in the Middle East.- New York/N.Y. u.a.: Encounter Books, 2009, 371 S.- ISBN 978-1-59403-232-5.

Phillips, David L., From bullets to ballots: violent Muslim movements in transition.- New Brunswick/ N.J. u.a.: Transaction Publ., 2009, X, 239 S.- ISBN 978-1-4128-0795-1.

Phillips, Sarah, Yemen's democracy experiment in regional perspective: patronage and pluralized authoritarianism.- New York/N.Y. u.a.: Palgrave Macmillan, 2008, VI,241 S.- ISBN 978-0-23060900-6.

Politischer Islam im Vorderen Orient: Zwischen Sozialbewegung, Opposition und Widerstand / Holger Albrecht; Kevin Köhler (Hrsg.).- Baden-Baden: Nomos Verl. Ges., 2008, 231 S.- ISBN 978-38329-4001-0.

Warkotsch, Alexander, The European Union's democracy promotion approach in Central Asia: on the right track?, in: European Foreign Affairs Review (London). 14 (May 2009) 2, S. 249-269. 


\section{LATEINAMERIKA / LATIN AMERICA}

Alberts, Susan, Why play by the rules?: Constitutionalism and democratic institutionalization in Ecuador and Uruguay, in: Democratization (Abingdon). 15 (December 2008) 5, S. 849-869.

Armijo, Leslie Elliott / Kearney, Christine A., Does democratization alter the policy process?: Trade policymaking in Brazil, in: Democratization (Abingdon). 15 (December 2008) 5, S. 991-1017.

Avritzer, Leonardo, Participatory institutions in democratic Brazil.- Baltimore/Md. u.a.: Johns Hopkins Univ. Press u.a. , 2009, 205 S.- ISBN 978-0-8018-9174-8.

Booth, John A. / Seligson, Mitchell A., The legitimacy puzzle in Latin America: political support and democracy in eight nations.- New York/N.Y.: Cambridge Univ. Press, 2009, XX, 355 S.- ISBN 978-0-521-51-589-4.

Brooks, Sarah M., Social protection and the market in Latin America: the transformation of social security institutions.- New York/N.Y.: Cambridge Univ. Press, 2009, VIII, 378 S.- ISBN 978-0521-87767-1.

Carey, John M., Legislative voting and accountability.- New York/N.Y.: Cambridge Univ. Press, 2008, 199 S.- ISBN 978-0-521-71191-3.

Evangelical christianity and democracy in Latin America / Ed. by Paul Freston.- New York/N.Y.: Oxford Univ. Press, 2008, XXII, 250 S.- ISBN 978-0-19-517476-2.

Gamboa Rocabado, Franco, Imposibilidad de acuerdos y polarización de la opinión pública: las campañas en contra y a favor de la constitución en Bolivia, aus: Análisis del referéndum constitucional 2009. / Fundacion Hanns Seidel.- FUNDEMOS: La Paz, 2009.- (Opiniones y Análisis; No. 98), S. 11-52.

Grijalva, Agustín, El estado plurinacional e intercultural en la constitución ecuatoriana del 2008, in: Ecuador Debate (Quito). (diciembre 2008) 75, S. 49-62.

Jahrbuch für Handlungs- und Entscheidungstheorie: Theorien der Verfassungsreform / Susumo Shikano u.a. (Hrsg.).- VS Verlag Sozialwissenschaft: Wiesbaden, 2009, 276 S.- ISBN 978-3-53116523-3.

Justicia de transición: con informes de América Latina, Alemania, Italia y España / Kai Ambos u.a. (eds.). Instituto Brasileiro de Ciências Criminais u.a..-- Montevideo: Mastergraf, 2009, 555 S.ISBN 978-9974-8099-6-3.

León Trujillo, Jorge G., Descentralización y autonomías en la Constitución de la Asamblea Constituyente de 2008, in: Ecuador Debate (Quito). (diciembre 2008) 75, S. 97-105.

López Sterup, Henrik, Consideraciones sobre el proyecto de reforma judicial: fortalecimiento o aislamiento de la rama judicial, in: Revista Foro (Bogotá). (noviembre 2008) 66, S. 93-103.

Minkner-Bünjer, Mechthild, Ecuador vor den Wahlen: geht Correas "Bürgerrevolution" weiter?.Hamburg: GIGA German Institute of Global and Area Studies, Institut für Lateinamerika-Studien, 2009, $8 \mathrm{~S}$.

Przeworski, Adam, The mechanics of regime instability in Latin America, in: Journal of Politics in Latin America (Hamburg). 1 (2009) 1, S. 5-36.

Reiter, Bernd, Negotiating democracy in Brazil: the politics of exclusion.- Boulder/Colo.: First Forum Press, 2009, 171 S.- ISBN 1-93504902-X. 
Root, Rebecca K., Through the window of opportunity: the transitional justice network in Peru, in: Human Rights Quarterly (Baltimore/Md.). 31 (May 2009) 2, S. 452-473.

Sánchez López, Francisco, Democracia no lograda o democracia malograda?: un análisis del sistema político del Ecuador, 1979-2002.- Quito: Facultad Latinoamericana de Ciencias Sociales, 2008, 269 S.- ISBN 978-9978-67-190-0.

Schneider, Aaron, Socio-economic changes and fiscal challenges in Central America: globalisation, democratisation, and the politics of reform, aus: The political economy of the public budget in the Americas / Diego Sánchez-Ancochea u.a. (eds). Institute for the Study of the Americas, Univ. of London.- London, 2008.- ISBN 978-1-900039-94-9, S. 163-199.- ISBN 978-1-900039-94-9.

Seifert, Karsten, Das interamerikanische System zum Schutz der Menschenrechte und seine Reformierung.- Frankfurt/Main: Lang, 2008, 358 S.- ISBN 978-3-63157680-9.

Speed, Shannon, Rights in rebellion: indigenous struggle and human rights in Chiapas.- Stanford/Cal.: Stanford University Press, 2008, XVII, 244 S.- ISBN 0-80475-734-8.

Valencia, María del Pilar / Égido, Iván, Bolivia: ¿Estado indio?: Reflexiones sobre el estado plurinacional en el debate constituyente boliviano, in: Verfassung und Recht in Übersee (BadenBaden). 42 (2009) 1, S. 55-72.

Veigel, Klaus Friedrich, Dictatorship, democracy, and globalization: Argentina and the cost of paralysis, 1973-2001.- University Park/Penn.: Pennsylvania State University Press, 2009, 234 S.ISBN 0-271-03464-5.

¿Volver a futuro?: Estado y mercado en América Latina, in: Nueva Sociedad (Buenos Aires). (mayojunio 2009) 221, S. 34-179. 